\title{
FERMENTASI TALAS BELITUNG (Xanthosoma sagittifolium (L.) Schott) DENGAN VARIASI RAGI DAN PENAMBAHAN NUTRISI DALAM MENGHASILKAN ETANOL
}

\author{
Mardiyah $^{1)}$, Srikandi $^{2)^{*}}$, RTM Sutamihardja ${ }^{1)}$ \\ ${ }^{1)}$ Program Studi Kimia, Fakultas MIPA, UNB Bogor \\ ${ }^{2)}$ Progam Studi Biologi, Fakultas MIPA, UNB Bogor \\ Jl. K.H. Sholeh Iskandar Km. 4 Cimanggu, Tanah Sareal, Bogor 16166 \\ Telp. 0251-8340217, 7535605 \\ e-mail: sriuus@yahoo.co.id
}

\begin{abstract}
Fermentation of Belitung Taro (Xanthosoma sagittifolium (L.) Schott) with variation of Yeast and Adding Nutrition to Produce Ethanol

Plants that are potential to produce bioethanol are plants that have sugar or carbohydrate levels one of which is Belitung taro (Xanthosoma sagittifolium). This research aims to make bioethanol with simple fermentation process with variation on yeast type (bread yeast and tape yeast) and with the addition of nutrients (NPK fertilizer) to obtain maximum bioethanol content. This research was begun by making taro pulp with four treatments and each treatment repeated 3 times. The four treatments consist of taro belt with yeast bread, yeast bread and NPK, yeast tape, yeast tape and NPK. Observations were performed on days 2, 4, 6, 7, 14 which included observation of pH and ethanol content. In addition, proximate test is also done. The results showed that the highest ethanol content in the fermentation process with yeast yeast occurred on the 7 th day of $3.64 \%$ while in the yeast tape the highest level occurred on the 4th day of $3.07 \%$. Addition of NPK can not produce maximum ethanol content. For proximate test, the result showed that the content of ash is high enough that is $4.57 \%$ while for carbohydrate, protein, fat, coarse fiber, and moisture content obtained results equivalent to the literature.
\end{abstract}

Keywords: Ethanol, Fermentation, Belitung Taro, Bioethanol

\begin{abstract}
ABSTRAK
Tumbuhan yang potensial untuk menghasilkan bioetanol adalah tanaman yang memiliki kadar gula atau karbohidrat salah satunya yaitu talas belitung (Xanthosoma sagittifolium). Penelitian ini bertujuan untuk membuat bioetanol dengan proses fermentasi sederhana dengan variasi pada jenis ragi (ragi roti dan ragi tape) serta dengan penambahan nutrisi (pupuk NPK) sehingga didapatkan kadar bioetanol yang maksimal. Diawali dengan membuat bubur talas belitung dengan empat perlakuan dan setiap perlakuan diulang 3 kali. Empat perlakuan terdiri atas talas belitung dengan ragi roti, ragi roti dan NPK, ragi tape, ragi tape dan NPK. Pengamatan dilakukan pada hari ke 2, 4, 6, 7, 14 yang meliputi pengamatan $\mathrm{pH}$ dan kadar etanol. Selain itu dilakukan juga uji proksimat. Hasil penelitian menunjukkan bahwa kadar etanol tertinggi pada proses fermentasi dengan ragi roti terjadi pada hari ke-7 yaitu $3,64 \%$ sedangkan pada ragi tape kadar tertinggi terjadi pada hari ke-4 yaitu 3,07\%. Penambahan NPK tidak dapat menghasilkan kadar etanol yang maksimal. Untuk pengujian proksimat didapatkan kadar abu yang cukup tinggi yaitu 4,57\% sedangkan untuk kadar karbohidrat, protein, lemak, serat kasar, dan kadar air didapatkan hasil yang setara dengan literatur.
\end{abstract}

Kata Kunci : Etanol, Fermentasi, Talas Belitung, Bioetanol

\section{PENDAHULUAN}

Kebutuhan akan energi yang kita butuhkan sangatlah tinggi. Semakin bertambahnya penduduk dan perkembangan tekhnologi yang demikian cepat dibutuhkan energi yang semakin besar sehingga pemakaian akan bahan bakar pun semakin besar. Persediaan bahan bakar yang ada saat ini sudah sangat terbatas dan diperlukan waktu ribuan tahun untuk dapat menghasilkan produk bahan bakar itu kembali (sulit diperbaharui), sehingga perlu dilakukan penghematan dalam pemakaiannya. Salah satu cara untuk dapat menghemat bahan bakar tersebut adalah dengan membuat produk alternatif yang dapat menggantikan fungsi dari bahan 
bakar tersebut. Produk bioetanol merupakan salah satu produk alternatif yang dapat menggantikan fungsi dari bahan bakar. Tumbuhan yang potensial untuk menghasilkan bioetanol adalah tanaman yang memiliki kadar gula atau karbohidrat tinggi seperti :tebu, nira, sorgum, sagu, ubikayu, ubi jalar, pisang dan talas.

Talas merupakan umbi dari batang tanaman dan merupakan salah satu tanaman sumber karbohidrat. Salah satu talas yang dikenal oleh masyarakat adalah talas belitung (Xanthosoma sagittifolium) atau sering disebut kimpul.

Pemanfaatan talas belitung yang masih kurang optimal dan informasi mengenai talas belitung pun masih sangat sedikit sehingga diperlukan penelitian lebih lanjut agar dapat memperoleh informasi yang sesuai. Untuk dapat memanfaatkan talas belitung agar dapat menghasilkan produk yang bernilai tinggi adalah dengan menjadikannya produk bioetanol.

Bioetanol $(\mathrm{C} 2 \mathrm{H} 5 \mathrm{OH})$ merupakan salah satu biofuel yang hadir sebagai bahan bakar alternatif yang lebih ramah lingkungan dan sifatnya yang terbarukan. Bioetanol dihasilkan dari proses fermentasi gula dari sumber karbohidrat (pati) menggunakan mikroorganisme (Anonim, 2007). Talas Belitung merupakan tanaman yang memiliki kandungan karbohidrat yang cukup tinggi, sehingga berpotensi untuk dapat menghasilkan bioetanol dengan bantuan mikroorganisme. Kelebihan bioetanol selain ramah lingkungan, penggunaannya sebagai campuran BBM terbukti dapat mengurangi emisi karbon monoksida dan asap lainnya dari kendaraan. Bioetanol juga bisa dijadikan pengganti bahan bakar minyak tanah. Selain hemat, pembuatannya dapat dilakukan di rumah dengan mudah, sehingga lebih ekonomis dibandingkan menggunakan minyak tanah.

\section{BAHAN DAN METODE}

\section{Bahan dan Alat}

Bahan yang digunakan yaitu Talas belitung kecil, ragi roti, ragi tape, pupuk NPK, K2Cr2O7, Ferro ammonium sulfat
(FAS), Indikator feroin, asam borat, petroleum eter, natrium bikromat, $\mathrm{KCl}, \mathrm{Na}-$ tiosulfat, $\mathrm{KIO}_{3}, \mathrm{NaOH}, \mathrm{KI}, \mathrm{H}_{2} \mathrm{SO}_{4}, \mathrm{BaCl}_{2}$, kanji, larutan luff dan campuran selenium.

Peralatan yang digunakan yaitu Neraca analitik, labu Kjedahl, kertas saring whatman, oven, tanur, corong Buchner, water bath, sentrifiuse, batang pengaduk, piala gelas, lemari es, cawan porselen, spatula, eksikator, soxhlet, erlenmeyer, buret, batu didih, indicator universal, pipet tetes, pipet volumetri, gelas ukur, pendingin tegak, labu ukur, hot plate, evaporator.

\section{Metode \\ 1. Preparasi Talas Belitung (Xanthosoma sagittifolium)}

Talas Belitung (Xanthosoma sagittifolium) didapatkan dari daerah Sukabumi dibersihkan dari tanah dan kotoran lain kemudian dikupas dan dicuci sampai bersih. Talas Belitung yang telah dikupas dan dicuci bersih kemudian dipotongpotong dan direbus selama 30 menit (sampai lunak). Perbandingan talas dan air pada proses perebusan yaitu 1:1. Selanjutnya talas didinginkan selama 15 menit (sampai uap menghilang) kemudian ditumbuk atau dihaluskan dengan menggunakan mortar sehingga didapatkan bubur talas.

\section{Proses Fermentasi}

Bubur talas yang telah jadi ditimbang 50 gram lalu ditambahkan air sebanyak $200 \mathrm{~mL}$, ragi roti 4 gram, ragi tape 4 gram dan pupuk NPK 0,4 gram. Selanjutnya dilakukan 4 percobaan sebagai berikut :

1. Talas Belitung + Ragi Roti 50 gram +4 gram

2. Talas Belitung + Ragi Roti + NPK : 50 gram +4 gram $+0,4$ gram

3. Talas Belitung + Ragi Tape 50 gram +4 gram

4. Talas Belitung + Ragi Tape + NPK : 50 gram +4 gram $+0,4$ gram

Preparasi yang telah siap kemudian ditutup dengan aluminium foil dan plastik sehingga proses fermentasi dapat dimulai. Proses fermentasi lakukan pada suhu ruang 25-30 ${ }^{\circ} \mathrm{C}$ dalam keadaan diam dimana 
pengamatan dilakukan pada hari ke 2, 4, 6, 7, dan 14.

\section{HASIL DAN PEMBAHASAN}

\section{Preparasi Talas Belitung}

Pengupasan dan pencucian talas berfungsi sebagai tahap awal untuk mengurangi kontaminasi dari bakteri lain pada saat proses fermentasi. Talas belitung yang telah dikupas dan dicuci bersih kemudian dipotong-potong dan direbus sampai melunak atau sampai menjadi bubur talas. Proses pelunakan (menjadi bubur) diperlukan untuk memperbesar luas permukaan agar ketika proses fermentasi ragi dapat tercampur merata dengan talas serta untuk memudahkan proses hidrolisis pati. Menurut Hambali et al. (2008) bahan padatan dikenai perlakuan pengecilan ukuran dan juga tahap pemasakan. Proses pengecilan ukuran dapat dilakukan dengan memotongnya menjadi bagian yang lebih kecil sebelum memasuki tahap pemasakan. Selanjutnya tahap pemasakan bahan meliputi proses likuifikasi dan sakarifikasi. Pemasakan juga dapat berfungsi untuk membunuh bakteri yang dapat berpotensi untuk menkontaminasi proses fermentasi.

\section{Proses Fermentasi}

Pengamatan terhadap proses fermentasi dilakukan pada hari ke 2, 4, 6, 7, dan 14. Ragi roti dan ragi tape berperan sebagai mikroba yang akan memfermentasi talas belitung, sedangkan penambahan NPK berfungsi sebagai penambahan nutrisi untuk mikroba agar mikroba dapat bertahan hidup dan dapat menghasilkan etanol yang lebih besar. Hasil Preparasi talas belitung sebelum dan setelah fermentasi dapat dilihat pada Gambar 1 .

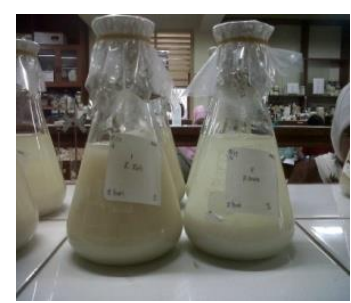

(a)

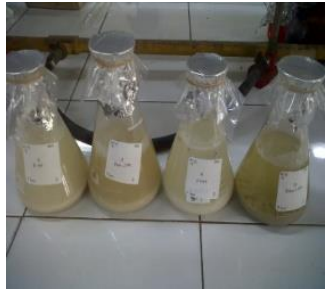

(b)

Gambar 1. Proses Fermentasi Talas Belitung Kecil (a) Sebelum (b) Setelah fermentasi

Dari hasil pengamatan proses fermentasi yang telah dilakukan dapat dilihat bahwa ketika proses fermentasi berlangsung akan menghasilkan gelembung $\left(\mathrm{CO}_{2}\right)$. Adanya penampakan gelembung disebabkan karena terbentuknya gas $\mathrm{CO}_{2}$ yang diakibatkan katabolisme secara anaerob dari gula yang ada dalam media dan hal ini mengindikasikan bahwa proses fermentasi sedang berlangsung. Gas $\mathrm{CO}_{2}$ yang timbul merupakan hasil samping dari proses fermentasi, ketika sudah tidak ada gelembung atau gas $\mathrm{CO}_{2}$ pada proses fermentasi maka dapat mengindikasikan bahwa proses fermentasi telah selesai.

\section{Pengujian pH Fermentasi}

Pengukuran $\mathrm{pH}$ setelah fermentasi dilakukan pada hari ke 2, 4, 6, 7, dan 14 . Pengukuran ini dilakukan untuk mengetahui apakah terjadi perubahan $\mathrm{pH}$ pada proses fermentasi pada setiap pengamatan. Dari data yang telah dihasilkan maka dapat diketahui bahwa terjadi perubahan $\mathrm{pH}$ pada proses fermentasi, dapat dilihat pada Gambar 2.

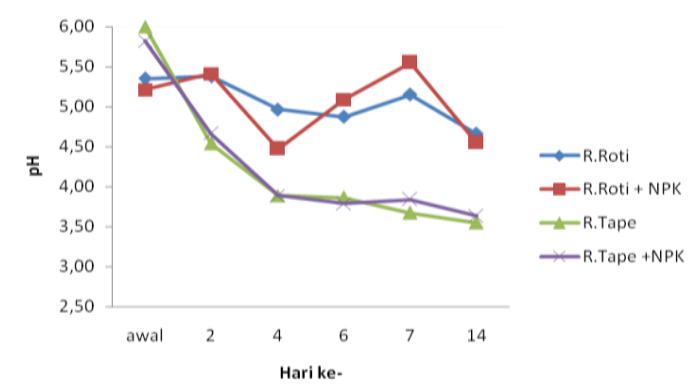

Gambar 2. Grafik Perubahan pH Terhadap Waktu Fermentasi 
Dari Gambar 2 dapat dilihat bahwa penurunan $\mathrm{pH}$ pada ragi roti dan ragi roti dengan NPK di hari ke-4 yaitu pH 4,96 dan 4,47 kemudian pada hari ke 6 untuk ragi roti terus menurun sampai $\mathrm{pH} \quad 4,87$ sedangkan untuk ragi roti dengan NPK terjadi kenaikkan menjadi $\mathrm{pH} \quad 5,50$ selanjutnya pada hari ke-7 ragi roti dan ragi roti dengan NPK naik kembali sampai $\mathrm{pH}$ 5,15 dan $\mathrm{pH}$ 5,55. Pada dari ke-14 ragi roti dan ragi roti dengan NPK keduanya turun sampai $\mathrm{pH} 4,66$ dan 4,55.

Pengamatan pada ragi tape dari awal fermentasi terus terjadi penurunan sampai hari ke-14 dengan $\mathrm{pH}$ 3,55 dan untuk ragi tape dengan NPK dari awal fermentasi juga terus terjadi penurunan $\mathrm{pH}$ namun sampai hari ke-6 yaitu 3,79 dan pada hari ke-7 terjadi sedikit kenaikkan yaitu 3,84 selanjutnya pada hari ke-14 kembali terjadi penurunan $\mathrm{pH}$ yaitu 3,63. Penurunan dan kenaikan $\mathrm{pH}$ sangat dipengaruhi oleh waktu proses fermentasi, hal ini disebabkan karena pada proses fermentasi masih terdapat mikroba yang terus berkembangbiak.

Perbedaan $\mathrm{pH}$ antara ragi roti dan ragi tape dapat dipengaruhi oleh kandungan dari ragi tersebut. Pada ragi roti yang terkandung hanya khamir Saccharomyces cereviciae sedangkan pada ragi tape selain Saccharomyces cereviciae terdapat mikroorganisme lain yang diperoleh dari ragi tersebut. Hal ini dapat menyebabkan $\mathrm{pH}$ yang dihasilkan dari kedua ragi ini berbeda. Mikroorganisme akan terus berkembangbiak dan menghasilkan suatu produk yang dapat mempengaruhi kondisi $\mathrm{pH}$ fermantasi, diantara produk yang dapat mempengaruhi pada proses ini yaitu asam asetat, etanol, $\mathrm{CO}_{2}$, dan sebagainya. Secara umum pada hari ke-14 pH cenderung menurun karena aktifitas enzim semakin lambat. Perubahan $\mathrm{pH}$ dalam fermentasi disebabkan karena dalam aktivitasnya sel khamir selain menghasilkan etanol sebagai metabolit primer juga menghasilkan asamasam organik seperti asam malat, asam tartarat, asam sitrat, asam laktat, asam asetat, asam butirat dan asam propionat sebagai hasil sampingan.

\section{Kadar Etanol Kasar dengan metode Titrasi}

Dari hasil penentuan kadar etanol dengan metode titrasi didapatkan kadar etanol. Pada ragi roti dengan atau tanpa penambahan NPK didapatkan hasil kadar etanol yang tertinggi berada pada hari ke-7 yaitu sekitar $2,76 \%$ dan 3,64\% kemudian akan turun kembali pada hari ke-14. Pada grafik juga dapat dilihat bahwa ragi roti memerlukan waktu yang lebih lama untuk dapat menghasilkan kadar etanol maksimum. Sedangkan untuk ragi tape hasil kadar etanol optimum terjadi pada hari ke-4 yaitu sekitar $2,64 \%$ dan $3,07 \%$ dan akan terus turun sampai hari ke-14 dan dapat dilihat juga bahwa ragi tape memerlukan waktu yang sebentar untuk dapat menghasilkan kadar etanol yang maksimum.

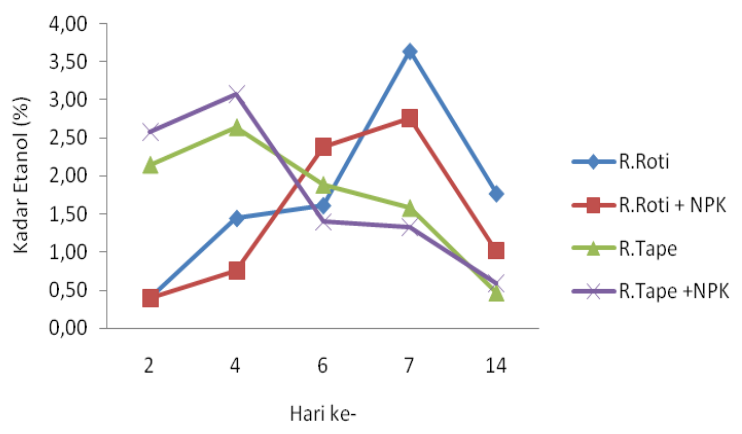

Gambar 3. Grafik Hasil Kadar Etanol

Terhadap Waktu Fermentasi

Penurunan kadar etanol yang terjadi pada proses fermentasi ini dapat dimungkinkan disebabkan karena aktifitas mikroorganisme yang ada dalam sampel sudah tidak optimal setelah hari ke-7 pada ragi roti dan hari ke-4 pada ragi tape. Perbedaan hari optimum dari kadar etanol yang dihasilkan dari ragi roti dan ragi tape dapat disebabkan karena pada ragi roti khamir yang digunakan lebih murni yaitu Saccharomyces cereviciae sehingga membutuhkan waktu yang lebih lama untuk dapat menghasilkan kadar etanol yang lebih tinggi.

Mikroorganisme lain dapat menghambat kerja dari Saccharomyces cerevicae sebagai mikroorganisme yang dapat menghasilkan etanol. Penambahan 
pupuk NPK sebagai nutrisi yang diharapkan dapat memperbesar kadar etanol. Jika dilihat dari grafik tidak menghasilkan kadar yang maksium pada ragi roti, hal ini mungkin pupuk NPK dapat menghambat proses fermentasi sedangkan pada ragi tape penambahan pupuk NPK dapat meningkatkan kadar etanol. Secara umum pada proses fermentasi di hari ke-14 menghasilkan kadar etanol yang cenderung menurun, hal ini disebabkan karena etanol yang dihasilkan telah menjadi asam asetat yang merupakan hasil samping dalam proses fermentasi.

\section{Analisis Proksimat}

Dari hasil pengujian kandungan proksimat yang telah dilakukan dan dibandingkan dengan literatur lain yang telah diperoleh, maka hasil uji pada umbi talas belitung dapat diperoleh grafik sebagai berikut :

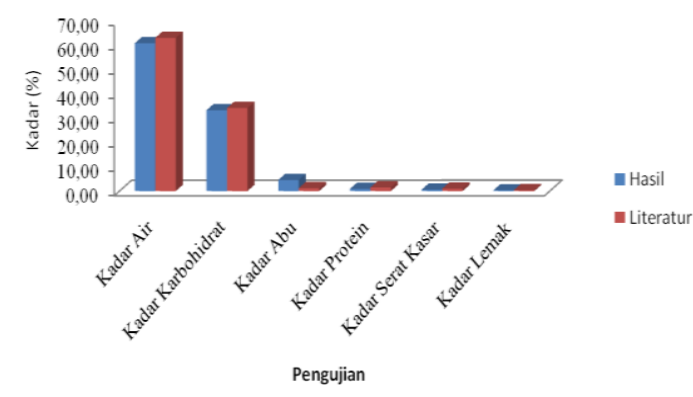

Gambar 4. Grafik Hasil Pengujian Kadar Proksimat Talas Belitung

Penentuan kadar proksimat ini dilakukan untuk mengetahui kandungan gizi dan sifat kimia dari talas belitung. Jika dilihat dari grafik yang telah dihasilkan maka dapat diketahui bahwa terdapat perbedaan hasil pengujian proksimat pada kandungan umbi talas belitung. Perbedaan yang nyata terjadi pada kadar abu dimana kandungan dari hasil analisis menghasilkan kadar $4,57 \%$ sedangkan pada literatur $1,20 \%$. Perbedaan ini dapat dipengaruhi oleh beberapa faktor salah satu diantaranya yaitu umur masa panen talas, karena talas belitung mempunyai umur masa panen sekitar 10-12 bulan yaitu ketika daun telah kering dan berwarna kuning (Indastri,2004). Ketika umbi talas dipanen belum pada waktunya maka dapat mempengaruhi kandungan kimia yang terdapat pada talas belitung karena umbi muda masih memiliki aktifitas metabolisme kimia dan biokimia (enzim) yang cukup tinggi (Muchtadi, 1992).

\section{KESIMPULAN}

Talas belitung kacil dapat menghasilkan etanol dengan fermentasi menggunakan ragi roti dan ragi tape. Kadar etanol kasar tertinggi dari proses fermentasi yang telah dilakukan terdapat pada ragi roti pada hari ke-7 sebesar 3.64\%. Penambahan pupuk NPK sebagai nutrisi tidak dapat menaikkan kadar etanol, serta pemakaian ragi yang berbeda (ragi roti dan ragi tape) membutuhkan waktu fermentasi yang berbeda untuk dapat menghasilkan kadar etanol yang maksimum.

\section{DAFTAR PUSTAKA}

AOAC. 1999. Official Methods of Analysis. Association of Official Analytical Chemist, Inc. Virginia.

Almatsier, S. 2001. Prinsip Sasar Ilmu Gizi. PT. Gramedia Pustaka Utama, Jakarta

Andarwulan, R., 2009. Lebih Jauh Tentang Ragi. $\quad h t t p: / / w w w . f e m i n a . c o . i d$. diakses tanggal 12 Maret 2013

Apriyantono, A. dkk 1989. Analisis Pangan. Pusat Studi Pangan dan Gizi. IPB, Bogor

Badan Standarisasi Nasional. 2009. SNI 3565-2009 : Etanol Nabati. Badan Standarisasi Nasional. Jakarta.

Buckle, K.A. 1985. Ilmu Pangan, UI.Press. Jakarta.

Desrosier, N. W., 1988. Teknologi Pengawetan Makanan. Penerjemahh M. Muljoharjo. UIPress, Jakarta. 
European Bioinformatics Institute. 1996.

Eukaryotes Genomes -

Saccharomyces

cerevisiae.http://www.emblebi.com /Saccharomyces_cerevisiae.htmlo9 8 [27 Februari 2013].

Fardiaz, S. 1992. Mikrobiologi Pangan I. PT Gramedia Pustaka Utama. Jakarta.

Frazier, W. C 1967. Food Microbiology $2^{\text {nd }}$ ed. Me Graw-Hill Book Co. New York

Hambali, E., S. Mujidalipah., A.H. Tambunan., A.W. Pattiwiri., dan R.Hendroko. 2008. Teknologi Bioenergi. AgroMedia Pustaka. Jakarta.

Hamidah, H. 2003. Produksi Alkohol. USU Press. Medan.

Harper,. Dan J. Laura 1986. Pangan, Gizi dan Pertanian. UI Press. Jakarta.

Kay, D.E .1973. Roots Crops. The Tropical Products Institute Foreign and Common Wealth Office. London.

Kim HR, Im YK, Ko HM, Chin JE, Kim IC, Lee HB, dan Bai S.2002. Fermentasi Pati Mentah Menjadi Etanol oleh Ragi Regangan suatu industri penyuling tentang Saccharomyces cerevisiae mengekskresikan gen glukoamilase dan $\alpha$-amilase. Universitas Nasional Chonnam. Korea Selatan.

Indrasti, Dias. 2004. Pemanfaatan Tepung Talas Belitung (Xanthosoma sagittifolium) Dalam Pembuatan Talas Belitung. Fakultas Teknologi IPB. Bogor.

Lingga, P., 1989. Bertanam ubi-ubian. Jakarta, Penebar Swadaya.

Maslahat, M. 2009. Pemanfaatan Selulosa Dari Limbah Kehutanan Untuk Produksi Bioetanol. Jurnal Nusa
Sylva Vol $9: 26-35$. Universitas Nusa Bangsa. Bogor.

Muchtadi, T. R dan Sugiyono. 1989. Petunjuk Laboratorium Ilmu Pengetahuan Bahan Pangan. Pusat Antar Universitas Pangan dan Gizi. Institut Pertanian Bogor. Bogor

Muljono, J., dan A.A Daewis, 1990, Teknologi Fermentasi, Pusat Antar Universitas Bioteknologi, Institute Pertanian Bogor, Bogor

Poedjiaji, A., dan T, Supriyanti. 1994. Dasar-Dasar Biokimia. UI Press. Jakarta.

Prihandana, R. dkk, 2008, Bioetanol Ubi Kayu Bahan Bakar Masa Depan, PT AgroMedia Pustaka, Jakarta.

Prescott,S. G and C. G. Dunn, 1959, Industrial Microbiology, ed 3, McGraw-Hill Book Company, New York.

Rahayu, E. S. dan Kuswanto, K. R. 1988. Teknologi Pengolahan Minuman Beralkohol. Yogyakarta: Universitas Gajah Mada.

Soerkarto, S.T. 1990. Dasar-dasar pengawasan dan Standarisasi Mutu Pangan. PAU Pangan dan Gizi. IPB Press, Bogor.

Sudarmadji, Slamet dkk. 1989. Analisa Bhan Makanan dan Pertanian. Yogyakarta : Liberty.

Sulianti dan Winianti PR. 1990. Teknologi Fermentasi Umni-Umbian dan Biji-Bijian. Bogor : PAU ITB

Tarigan, J. 1990. Pengantar Mikrobiologi Umum. Departemen Pendidikan dan Kebudayaan Direktorat Jenderal Pendidikan Tinggi. Jakarta Winarno, F. G. 1997. Kimia Pangan dan Gizi. Gramedia. Jakarta. 
Winarno, F. G. 1995. Kimia Pangan Dan

Utaman

Gizi. Jakarta : Gramedia Pustaka 